\title{
Influence of type of metal alloy and penetration limit in determining the working
}

\section{length with two apex locators}

\author{
Influência do tipo de liga metálica e do limite de penetração na determinação do comprimento de \\ trabalho com dois localizadores apicais
}

Influencia del tipo de aleación de metal y del límite de penetración en la determinación de la longitud de trabajo con dos localizadores de ápice

Enio Cordeiro Amaral

ORCID: https://orcid.org/0000-0001-7464-6849 Faculdade São Leopoldo Mandic, Brasil E-mail: enio_cordeiro@hotmail.com

Juliana Larocca de Geus ORCID: https://orcid.org/0000-0001-9633-0474 Faculdade Paulo Picanço, Brasil E-mail: juliana.degeus@ facpp.edu.br

Bruno Carvalho de Vasconcelos ORCID: https://orcid.org/0000-0003-4415-5680 Universidade Federal do Ceará, Brasil E-mail: bcv@ufc.br

Nilton Vivacqua-Gomes

ORCID: https://orcid.org/0000-0002-0096-9802 Faculdade São Leopoldo Mandic, Brasil E-mail: profesornilton@yahoo.com.br

\begin{abstract}
This ex vivo study aimed to evaluate the precision of two electronic foramen locators (Root ZX mini and RomiApex A15) inserting the manual Flexofile or NiTi endodontic files until reaching the apical foramen or surpassing it. Sixty mesial root canals of mandibular molars were selected. Root canal real length measurement and odontometry were performed after the access cavity surgery, cervical pre-flaring, and apical preparation. The precision of the electronic foramen locators was verified at each instrumentation phase, comparing the electronic measurements with the real length. The 3-way ANOVA test was used to evaluate the error of electronic measurements, and a significance level was set at 5\%. At the first odontometry, the RZX was significantly more precise than the A15 ( $<<0,0001)$. After the second odontometry, the best results were observed when the penetration limit was restricted to the apical foramen. After the third odontometry, statistical differences were found for apex locator $(p<0,0001)$, penetration limit $(p<0,05)$, and metallic alloy $(\mathrm{p}=0,01)$. Manual instruments used to perform the odontometry should be inserted only until the foramen level. The use of NiTi files improves the precision of electronic foramen locators.
\end{abstract}

Keywords: Alloys; Endodontics; Odontometry.

\section{Resumo}

O objetivo deste estudo ex vivo foi avaliar a precisão de dois localizadores apicais (Root ZX mini e RomiApex A15) inserindo as limas endodônticas manuais Flexofile ou NiTi até atingir o forame apical ou ultrapassá-lo. Sessenta canais radiculares mesiais de molares inferiores foram selecionados. A mensuração do comprimento real do canal radicular e a odontometria foram realizadas após a cirurgia de acesso, pré-alargamento cervical e preparo apical. A precisão dos localizadores apicais foi verificada a cada fase de instrumentação, comparando as medidas eletrônicas com o comprimento real. O teste ANOVA de 3 fatores foi usado para avaliar o erro das medidas eletrônicas e o nível de significância foi estabelecido em 5\%. Na primeira odontometria, o RZX foi significativamente mais preciso do que o A15 ( $p<0,0001$ ). Após a segunda odontometria, os melhores resultados foram observados quando o limite de penetração ficou restrito ao forame apical. Após a terceira odontometria, foram encontradas diferenças estatísticas para localizador apical $(\mathrm{p}<0,0001)$, limite de penetração $(\mathrm{p}<0,05)$ e liga metálica $(\mathrm{p}=0,01)$. Os instrumentos manuais utilizados para a realização da odontometria devem ser inseridos somente até o nível do forame. $\mathrm{O}$ uso de limas NiTi melhora a precisão dos localizadores apicais.

Palavras-chave: Ligas; Endodontia; Odontometria. 


\section{Resumen}

El objetivo de este estudio ex vivo fue evaluar la precisión de dos localizadores de ápice (Root ZX mini y RomiApex A15) insertando las limas endodónticas manuales Flexofile o NiTi hasta llegar al foramen apical o superarlo. Se seleccionaron sesenta conductos radiculares mesiales de molares mandibulares. La medición de la longitud real del conducto radicular y la odontometría se realizaron después de la cirugía de la cavidad de acceso, el abocardado cervical y la preparación apical. La precisión de los localizadores de ápices se verificó en cada fase de instrumentación, comparando las medidas electrónicas con la longitud real. Se utilizó la prueba ANOVA de 3 vías para evaluar el error de las mediciones electrónicas y se estableció un nivel de significancia del 5\%. En la primera odontometría, el RZX fue significativamente más preciso que el A15 ( $\mathrm{p}<0,0001$ ). Después de la segunda odontometría, los mejores resultados se observaron cuando el límite de penetración se restringió al foramen apical. Después de la tercera odontometría, se encontraron diferencias estadísticas para localizador de ápice (p <0,0001), límite de penetración $(\mathrm{p}<0,05)$ y aleación metálica $(\mathrm{p}=0,01)$. Los instrumentos manuales utilizados para realizar la odontometría deben insertarse solo hasta el nivel del foramen. El uso de limas NiTi mejora la precisión de los localizadores de ápices.

Palabras clave: Aleaciones; Endodoncia; Odontometría.

\section{Introduction}

The use of electronic foramen locators (EFL) is an established method described by the literature as efficacious to determine the real length of the root canal, reaching precision levels above 90\% (Nekoofar et al. 2006, Martins et al. 2014, Khandewal et al. 2015, Piasecki et al. 2016, Üstün et al. 2016). When choosing to perform the electronic odontometry (ODM), it is known that the type of endodontic file used and the apical penetration limit until which such instrument is inserted significatively influence the precision of EFL (de Vasconcelos et al. 2015, Oliveira et al. 2017, Serna-Peña et al. 2020).

The novel EFL are based on the frequency-dependent impedance method. The impedance depends on the resistance and capacitance, which are electric factors. Resistance is the energy transmitted by the device throughout the tip of the instrument and is associated with the apical penetration limit of the endodontic files. Capacitance is the energy released along with the instrument and is associated with its adaptation to the root canal walls (Nekoofar et al. 2016, Vasconcelos et al. 2020). Understanding the functioning of EFL, it seems more suitable to use instruments adjusted to the root canal walls (Vasconcelos et al. 2012). However, it has been demonstrated that the tactile perception of adjustment of the instrument to the apical foramen is not necessarily due to the contact of the instrument with the apex once such perception might result from interferences at the coronal and/or medium thirds of the root canal (Leeb 1983, Paqué et al. 2010). In this context, the preparation of the cervical and medium thirds of the root canal previously to the odontometry is important to remove interferences and allow a better adjustment of the endodontic file to the apical foramen (Pécora et al. 2005, de Camargo et al. 2009).

Another factor frequently non-considered during the selection of an instrument to perform the odontometry is the type of metallic alloy of the endodontic file and its influence in the adjustment to the apical foramen. For instance, stainless-steel files might not perform well in following the shape of dilacerated root canals, such as the ones of mesial roots of mandibular molars, which would be better accessed with NiTi instruments (Walia et al. 1988, Thompson 2000). In this regard, a study comparing stainless-steel to NiTi instruments demonstrated that the diameter of the NiTi instrument tip that passively reached the apical foramen was 2 or 3 times larger than the one of the stainless-steel instruments, even after the preparation of the cervical and medium thirds of the root canal (Paqué et al. 2010). Crossing these findings with the capacitance of the EFL, it seems that since NiTi files adapt better to the apical foramen, they could influence the precision of apical locator devices (Thomas et al. 2003, Stöber et al. 2011, Duran-Sindreu et al. 2012, Vasconcelos et al. 2013, Gehlot et al. 2016, Vasconcelos et al. 2016, Altunbaş et al. 2017, Chaudhary et al. 2018). Nonetheless, only a few investigations have addressed the influence of manual NiTi instruments on the precision of EFL.

In relation to the penetration limit of endodontic files, recent studies have shown that electronic foraminal locators are more accurate when the endodontic file is inserted up to the limit of the apical foramen (0.0) of the devices (Stöber et al. 2011, 
Oliveira et al. 2017). However, some professionals use to surpass such limit during the odontometry to "confirm the patency" or to "close the circuit", then they replace the endodontic file to the 0.0 position. To the extent of our knowledge, only one study in the literature has addressed the precision of EFL when the endodontic file surpasses the apical foramen, reaching the "over" position during the electronic odontometry (Oliveira et al. 2017).

Given the exposed, our ex vivo study aimed to evaluate the precision of two EFL, Root ZX mini (J Morita Corp., Kyoto, Japan) and RomiApex A15 (Romidan, Kiryat Ono, Israel), inserting the manual Flexofile or NiTi endodontic files until reaching the apical foramen (0.0) or surpassing it (OVER/0.0). Moreover, manual stainless-steel and NiTi endodontic files were used to evaluate if the metallic alloy would influence the adjustment of the instrument to the apical foramen, interfering in the precision of the EFL.

\section{Methodology}

This is an ex vivo study (Pereira et al. 2018) approved by the local Ethics Committee (no: 4.359.542).

\section{Sample size}

The sample size of this study was calculated based on a pilot study considering a significance level of 0.05 , a beta error of 0.8 , and an N1/N2 ratio of 1 . The calculation indicated that 60 samples would be needed to find statistical differences among groups.

\section{Eligibility criteria}

Mandibular molars with Vertucci class IV mesial roots (Vertucci 1974) without pronounced dilaceration $\left(<25^{\circ}\right)$ and with apical foramen measuring from 200 to $300 \mu \mathrm{m}$ were selected (Vasconcelos et al. 2015), totalizing 60 root canals.

\section{Protocol}

A manual NiTi endodontic file (Dentsply-Sirona, Baillagues, Switzerland), that fits snugly in the root canal, was inserted into the root canal until its tip could be seen throughout the apical foramen with the aid of an operative microscope (Alliance, São Carlos, SP, Brazil) using a magnification of 16x. At this moment, the tip of the file needed to be adjusted to the apical foramen for the root canal real length (RCRL) to be determined. The measurement of the RCRL was obtained in triplicate with the aid of a digital pachymeter (Mitutoyo, Suzano, SP, Brazil). The real length 1 (RL1) was defined as the means obtained from the three measurements. Only root canals with a real length of $18.0 \pm 1.0 \mathrm{~mm}$ were included in this study.

After, the odontometry was performed before the cervical pre-flaring of the root canal (ODM1). The tooth was inserted into a plastic recipient containing alginate (Ava Gel, Dentsply Ind. e Com. Ltda, Petrópolis RJ, Brazil) until reaching the cement-enamel junction (Vasconcelos et al. 2015). The alginate was prepared according to the manufacturer's instructions.

To perform the measurements, the root canals were filled with saline (Biodinâmica, Ibiporã, PR, Brazil). The endodontic file connected to the EFL was inserted into the root canal until the device indicates the 0.0 position. If the selected instrument could not reach the apical foramen, the endodontic file was changed for another one with a thinner tip. At this moment, the rubber stopper of the endodontic file was positioned at the occlusal board of the molar crown. After that, the instrument was removed from the root canal and a blind and experienced examiner measured the distance from the rubber stopper to the tip of the endodontic file using a digital pachymeter (Mitutoyo). The tip of the file used in each electronic measurement was also recorded. There was a shift between the use of NiTi and Flexofile (Dentsply - Sirona) files as well as between the use of the RZX and A15 foramen locators. 
After the measurement at the 0.0 position, a new measurement was performed. This time, the endodontic file should reach the 0.0 position. Then, it was inserted until surpassing the apical foramen to reach the OVER position. After that, the instrument was replaced at the 0.0 position, which was verified using the display of the apex locator.

Once the initial electronic measurements were concluded, the apical and medium thirds of dental root canals were chemically and mechanically prepared by employing the crown-down technique using a rotatory instrument 25.08 (Prodesign S System, Bassi Equipamentos Odontologicos) powered by an electrical motor at 600 RPM and torque at 3N.cm (X-Smart Plus, Dentsply-Sirona). This instrument was $4 \mathrm{~mm}$ shorter than the real length 1 (RL1) of the root canal previously determined. Then, the real length of the dental root canal after the cervical preparation was determined (RL2) as described for RL1. Finally, electronic measurements after the cervical preparation, odontometry 2 (ODM2), were carried out similarly to ODM1.

By the time the electronic measurements after the cervical preparation were finished, the apical preparation of the dental root canals was performed. This step employed the crown-down technique using a reciprocating instrument 25.06 (Prodesign R System) powered by an electric motor at program "WaveOne". This initial apical preparation was finished as soon as the instrument reached RL2 $+1 \mathrm{~mm}$. The refinement of the apical preparation was achieved by using the crown-down technique with a rotatory instrument 35.05 (Logic 2 System) powered by an electric motor at 450 RPM and torque $2 \mathrm{~N}$ until the instrument reached RL2 $+1 \mathrm{~mm}$, so the final preparation advanced $1 \mathrm{~mm}$ beyond the apex.

Next, the real length of the dental canal was established after the apical preparation was finished (RL3) and the electronic measurements were performed, odontometry 3 (ODM3), as previously described.

The precision of the EFL was assessed by comparing the values obtained by electronic measurements (ODM) and the real length of the root canal (RL) to evaluate the mean error of the devices in millimeters. To determine the device's precision, $\mathrm{a} \pm 0.5 \mathrm{~mm}$ margin was established as a tolerance margin.

\section{Statistical analysis}

Data normality was assessed, the 3-way ANOVA test was used to evaluate the error of electronic measurements, and a significance level was set at 5\%. This statistical test grouped the specimens according to the electronic foramen locator (RZX and A15), penetration limit (0.0 and over/0.0), and metallic alloy (flex and NiTi) in separate analyses. When 3-way ANOVA was employed, each of these analyses grouped the four groups containing the same selected factor, yielding an experimental $\mathrm{n}$ of 240. The program used for statistical analyses was BioStat PRO 7.3 (AnalystSoft Inc. - USA).

\section{Results}

Table 1 depicts the means in millimeters and errors obtained from the electronic measurements during ODM1 (after access cavity and patency). At the analysis of ODM1, a significant difference was found only for the factor foramen locator $(\mathrm{p}<0.0001)$. No difference was found for the factors endodontic file and technique $(\mathrm{p}>0.05)$. 
Table 1. Mean errors (mm) provided by electronic measurements during ODM1 (after access).

\begin{tabular}{|c|c|c|c|c|c|}
\hline FACTOR & GROUP & SAMPLE SIZE & MEAN & $S D$ & $p^{*}$ \\
\hline \multirow[t]{2}{*}{ Locator } & $A 15$ & 240 & $0.2558^{\mathrm{b}}$ & 0.1840 & \\
\hline & $R Z X$ & 240 & $0.1855^{\mathrm{a}}$ & 0.1231 & $\mathrm{p}<0.0001$ \\
\hline \multirow[t]{2}{*}{ Penetration limit } & OVER/O.O & 240 & $0.2322^{\mathrm{a}}$ & 0.1729 & \\
\hline & 0.0 & 240 & $0.2091^{\mathrm{a}}$ & 0.1461 & $\mathrm{p}>0.05$ \\
\hline \multirow[t]{2}{*}{ Metal alloy } & FLEX & 240 & $0.2220^{\mathrm{a}}$ & 0.1715 & \\
\hline & NITI & 240 & $0.2194^{\mathrm{a}}$ & 0.1486 & $\mathrm{p}>0.05$ \\
\hline
\end{tabular}

*ANOVA 3-factors test. Different superscript lower case letters indicate statistically significant differences.

Source: The authors

Table 2 show the mean errors $(\mathrm{mm})$ provided by electronic measurements during ODM2 (after cervical preparation). After ODM2, a statistical significance was found for the factor's foramen locator and penetration limit $(p<0.0001)$, whereas no difference was found for the factor metallic alloy $(p>0,05)$. 
Table 2. Mean errors ( $\mathrm{mm}$ ) provided by electronic measurements during ODM2 (after cervical preparation).

\begin{tabular}{lccccc}
\hline \multicolumn{1}{c}{ FACTOR } & GROUP & SAMPLE SIZE & MEAN & SD & $\boldsymbol{P}^{*}$ \\
\hline \multirow{2}{*}{ Locator } & $A 15$ & 240 & $0.3382^{\mathrm{b}}$ & 0.2247 & \\
& $R Z X$ & 240 & $0.2248^{\mathrm{a}}$ & 0.1941 & $\mathrm{p}<0.0001$ \\
\hline Penetration limit & OVER/0.0 & 240 & $0.3178^{\mathrm{b}}$ & 0.2276 & \\
& 0.0 & 240 & $0.2452^{\mathrm{a}}$ & 0.2004 & $\mathrm{p}<0.0001$ \\
\hline \multirow{2}{*}{ Metal alloy } & FLEX & 240 & $0.2839^{\mathrm{a}}$ & 0.2156 & \\
& NITI & 240 & $0.2790^{\mathrm{a}}$ & 0.2194 & $\mathrm{p}>0.05$
\end{tabular}

*ANOVA 3-factors test. Min letters different superscript letters indicate statistically significant differences.

Source: The authors

Table 3 show the mean errors $(\mathrm{mm})$ provided by electronic measurements during ODM3 (after apical preparation). The analysis of ODM3 revealed significant statistical differences in all three comparisons: foramen locator $(\mathrm{p}<0.0001)$, penetration limit $(\mathrm{p}<0.05)$, and metallic alloy $(\mathrm{p}=0.01)$. 
Table 3. Mean errors ( $\mathrm{mm}$ ) provided by electronic measurements during ODM3 (after apical preparation).

\begin{tabular}{lccccc}
\hline FACTOR & GROUP & SAMPLE SIZE & MEAN & SD & $\boldsymbol{p}^{*}$ \\
\hline Locator & A15 & 240 & $0.3139^{\mathrm{b}}$ & 0.2144 & \\
& RZX & 240 & $0.1759^{\mathrm{a}}$ & 0.1758 & $\mathrm{p}<0.0001$ \\
\hline Penetration limit & OVER/0.0 & 240 & $0.2625^{\mathrm{b}}$ & 0.2203 & \\
& 0.0 & 240 & $0.2273^{\mathrm{a}}$ & 0.1932 & $\mathrm{p}<0.05$ \\
\hline Metal alloy & FLEX & 240 & $0.2672^{\mathrm{b}}$ & 0.2240 & \\
& NITI & 240 & $0.2226^{\mathrm{a}}$ & 0.1878 & $\mathrm{p}=0.01$ \\
\hline
\end{tabular}

*ANOVA 3-factors test. Different superscript lower case letters indicate statistically significant differences.

Source: The authors

Figures 1, 2, and 3 show the error distribution in the $0.25 \mathrm{~mm}$ range during ODM1, ODM2, and ODM3, respectively.

Figure 1. Distribution of errors provided by electronic measurements during ODM1 (after access and patent).

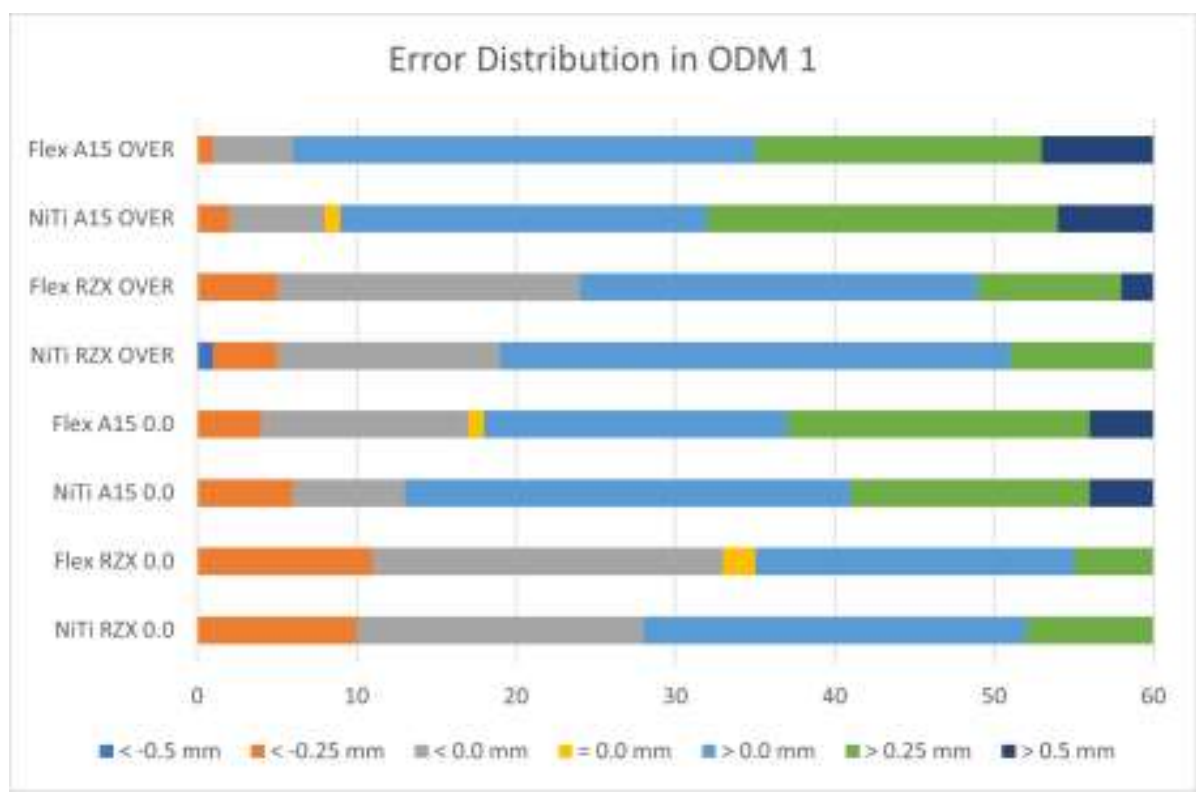

Source: The authors. 
Research, Society and Development, v. 11, n. 2, e11911225544, 2022

(CC BY 4.0) | ISSN 2525-3409 | DOI: http://dx.doi.org/10.33448/rsd-v11i2.25544

Figure 2. Distribution of errors provided by electronic measurements during ODM2 (after cervical preparation).

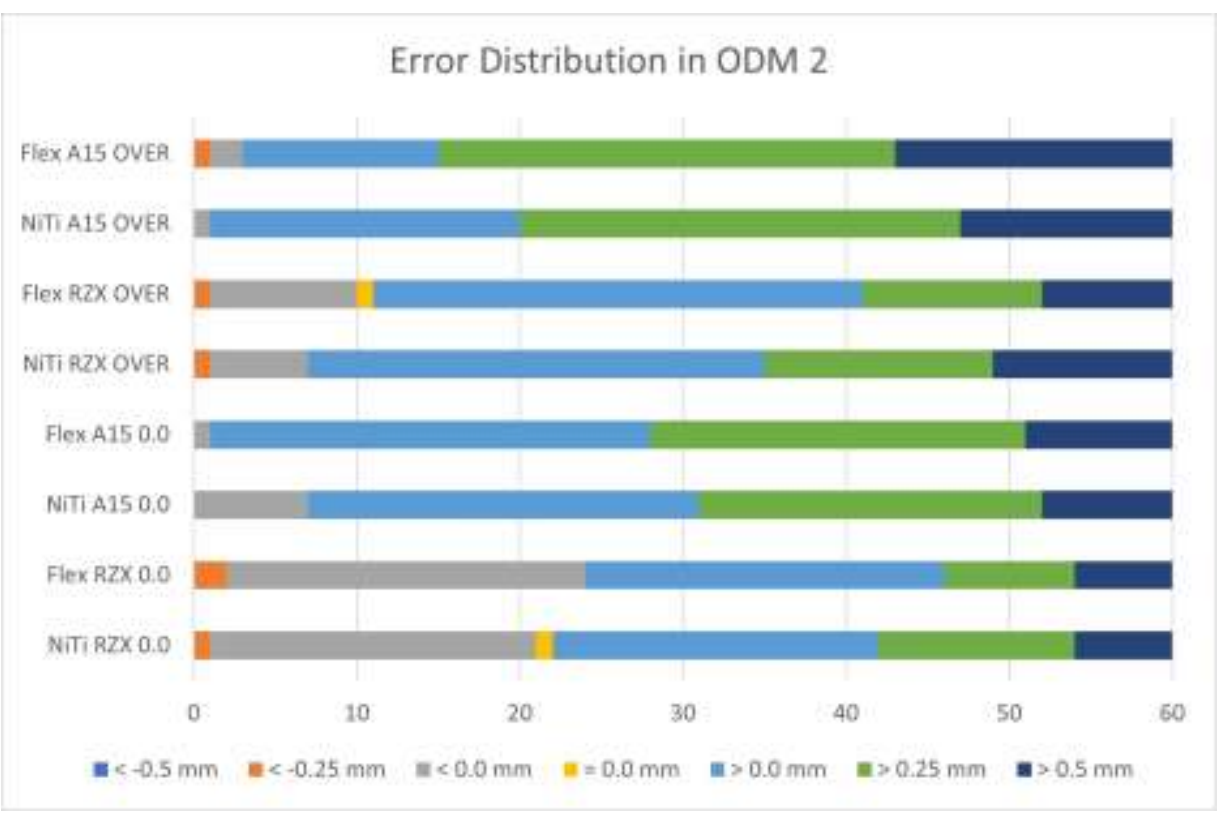

Source: The authors.

Figure 3. Distribution of errors provided by electronic measurements during ODM3 (after apical preparation).

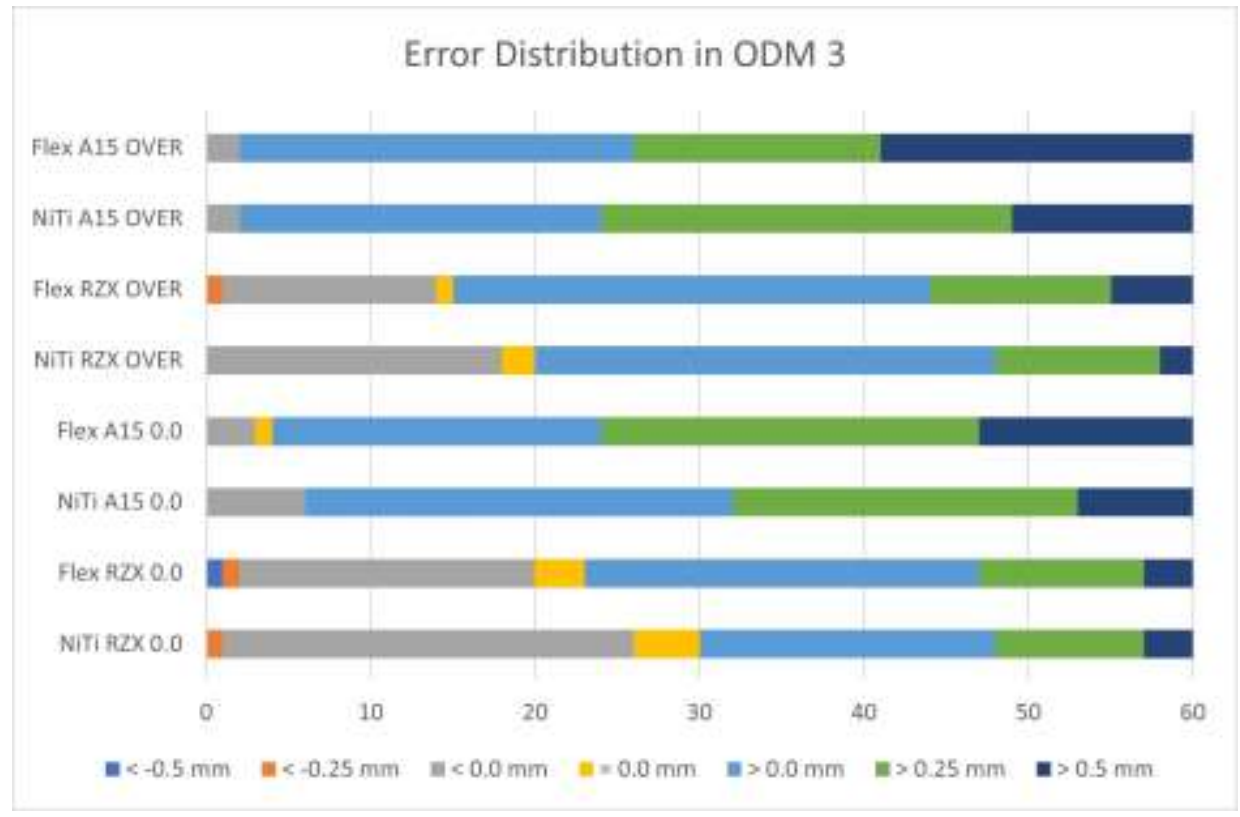

Source: The authors. 
Table 4 presents the median of the instruments employed during the electronic measurements in each phase of chemical-mechanical preparation. In ODM1 the median varied between 20 to 25 . In ODM2 al instruments presented a median of 25. In ODM3 all NiTi instruments presents a median of 40 and all flex instruments presented a median of 35 .

Table 4. Median of the instruments employed during the electronic measurements in each phase of chemicalmechanical preparation.

\begin{tabular}{|c|c|c|c|c|c|c|c|c|}
\hline ODM1 & GROUP & MEDIAN & ODM2 & GROUP & MEDIAN & ODM3 & GROUP & MEDIAN \\
\hline$R Z X 0.0$ & $\begin{array}{l}\text { NiTi } \\
\text { Flex }\end{array}$ & $\begin{array}{l}20 \\
20\end{array}$ & RZX 0.0 & $\begin{array}{l}\mathrm{NiTi} \\
\text { Flex }\end{array}$ & $\begin{array}{l}25 \\
25\end{array}$ & $R Z X 0.0$ & $\begin{array}{l}\mathrm{NiTi} \\
\text { Flex }\end{array}$ & $\begin{array}{l}40 \\
35\end{array}$ \\
\hline A15 0.0 & $\begin{array}{l}\mathrm{NiTi} \\
\text { Flex }\end{array}$ & $\begin{array}{c}22.5 \\
20\end{array}$ & A15 0.0 & $\begin{array}{l}\mathrm{NiTi} \\
\text { Flex }\end{array}$ & $\begin{array}{l}25 \\
25\end{array}$ & A15 0.0 & $\begin{array}{l}\mathrm{NiTi} \\
\text { Flex }\end{array}$ & $\begin{array}{l}40 \\
35\end{array}$ \\
\hline RZX OVER & $\begin{array}{l}\mathrm{NiTi} \\
\text { Flex }\end{array}$ & $\begin{array}{l}25 \\
25\end{array}$ & RZX OVER & $\begin{array}{l}\mathrm{NiTi} \\
\text { Flex }\end{array}$ & $\begin{array}{l}25 \\
25\end{array}$ & RZX OVER & $\begin{array}{l}\mathrm{NiTi} \\
\text { Flex }\end{array}$ & $\begin{array}{l}40 \\
35\end{array}$ \\
\hline A15 OVER & $\begin{array}{l}\mathrm{NiTi} \\
\text { Flex }\end{array}$ & $\begin{array}{l}25 \\
25\end{array}$ & A15 OVER & $\begin{array}{l}\mathrm{NiTi} \\
\text { Flex }\end{array}$ & $\begin{array}{l}25 \\
25\end{array}$ & A15 OVER & $\begin{array}{l}\mathrm{NiTi} \\
\text { Flex }\end{array}$ & $\begin{array}{l}40 \\
35\end{array}$ \\
\hline
\end{tabular}

Source: The authors.

\section{Discussion}

The results found during ODM1 revealed no statistically significant difference regarding the penetration limit of the instruments. However, by analyzing the error distribution, the penetration limit OVER/0.0 generated measurements farther way the apical foramen in $75.8 \%$ of the specimens. Whereas protocol 0.0 generated fewer measurements away from the apical foramen $(60.83 \%)$. Also, no difference was found for the factor metallic alloy, and the median of the tips of endodontic files varied between \#20 to \#25. Regarding the factor "foramen locator", a significant difference existed: Root ZX obtained a mean error of $0.18 \mathrm{~mm}$ and $98.75 \%$ precision, whilst RomiApex A15 scored $0.25 \mathrm{~mm}$, reaching $91.25 \%$ precision when locating the apical foramen.

After the cervical and mid thirds preparation was concluded, ODM2 was taken. In this group, no statistically significant difference was found between the electronic locators. Root ZX Mini presented a mean error of $0.22 \mathrm{~mm}$, considering $\pm 0.5 \mathrm{~mm}$ as tolerance margin, and $87.08 \%$ of precision. RomiApex A15 showed a mean error of $0.33 \mathrm{~mm}$ and a precision of $80.42 \%$. Also, no statistical difference was found for the factor "metallic alloy", but the median values for the tip of the endodontic file used was \#25 for both groups NiTi and Flex, being slightly larger than the values found for ODM1, which denotes that the preparation of the mid and cervical thirds increases the adjustment of the instrument tip into the apical foramen (Paqué et al. 2010, Pécora et al. 2005). Concerning the penetration limit of instruments, a statistically significant difference between groups was found. The insertion protocol up to 0.0 yielded a mean error of $0.24 \mathrm{~mm}$, being closer to the apical foramen than protocol OVER/0.0, which in turn presented a mean error of $0.31 \mathrm{~mm}$.

In ODM3, again, a significant difference was found between foramen locators. Root ZX Mini showed 94.71\% precision, whereas RomiApex A15 revealed only 79.17\%. Regarding the penetration limit, the insertion protocol to reach the apical foramen (0.0) obtained a mean error of $0.22 \mathrm{~mm}$ and $73.75 \%$ of measurements surpassing it, while the insertion protocol OVER/0.0 reached a mean error value of $0.26 \mathrm{~mm}$ and measurements away from the apical foramen in $83.75 \%$

of the specimens. It is possible to observe that protocol OVER/0.0 generated a higher frequency of measurements 
surpassing the apical foramen compared to protocol 0.0. These findings corroborate with Vasconcelos et al. (2015) who demonstrated that protocol OVER/0.0 afforded inferior outcomes than when the instrument only reached the apical foramen (0.0). This decrease in precision might be caused by a slight apical misfit of the instrument when it passes through the foramen and returns through it, influencing the impedance of electronic foramen locators (Vasconcelos et al. 2015).

It was only in ODM3 that statistically significant differences could be observed regarding the type of metallic alloy. The endodontic file NiTi presented more satisfactory results $(0.22 \mathrm{~mm})$ than stainless steel files $(0.26 \mathrm{~mm})$, influencing the precision of the electronic foramen locators tested. Another important finding was regarding the tip of the instrument used for odontometry. The median value of the tips of NiTi files was \#40, while stainless steel files presented\#35 as median values. This could be due to the flexibility of the flexofile instruments \#30, \#35, and \#40 varies from 50 to 120 g.cm, whilst NiTi files of the same caliber vary from 30 to $50 \mathrm{~g} . \mathrm{cm}$ (Leonardo \& Leonardo 2017). Thus, for the chemical and mechanical preparation of teeth whose roots present curvatures, the force applied onto a flexofile of a larger diameter is extremely high, which prevents the file from reaching the apical foramen, being necessary to use instruments of thinner caliber to do it and to perform odontometry.

Several limitations of this study should be taken into consideration, as the clinical situation may be different from this ex vivo experimental model. This may be the case in curved canals (Hartmann et al. 2019); oval canals (Paqué et al. 2010); or immature tooth (Trope 2010). Further studies will be necessary to investigate EAL accuracy in these clinical situations.

\section{Conclusion}

Under the conditions of this study, it can be concluded that manual instruments used for odontometry should be inserted up to the foramen level (0.0), without reaching the periodontal ligament space (OVER/0.0). NiTi and stainless-steel instruments could be interchangeably used during the initial odontometry. During the final odontometry, NiTi files increased the precision of the electronic foramen locators tested.

\section{Acknowledgments}

This research did not receive any specific grant from funding agencies in public, commercial or not-for-profit sectors.

\section{References}

Altunbaş, D., Kuştarcı, A., \& Toyoğlu, M. (2017) The Influence of Various Irrigants on the Accuracy of 2 Electronic Apex Locators in Locating Simulated Root Perforations. Journal of Endodontics 43(3):439-442.

Camargo, E.J., Zapata, R.O., Medeiros, P.L., Bramante, C.M., Bernardineli, N., Garcia, R.B., de Moraes, I.G., \& Duarte, M.A. (2009) Influence of preflaring on the accuracy of length determination with four electronic apex locators. Journal of Endodontics 35(9):1300-1302.

Chaudhary, S., Gharti, A., \& Adhikari, B. (2018) An in vivo comparison of accuracy of two electronic apex locators in determining working length using stainless steel and nickel titanium files. Clinical, Cosmetic and Investigational Dentistry 10:75-82.

Duran-Sindreu, F., Stöber, E., Mercadé, M., Vera, J., Garcia, M., Bueno, R., \& Roig, M. (2012) Comparison of in vivo and in vitro readings when testing the accuracy of the Root ZX apex locator. Journal of Endodontics 38(2):236-239.

Gehlot, P.M., Manjunath, V., \& Manjunath, M.K. (2016) An in vitro evaluation of the accuracy of four electronic apex locators using stainless-steel and nickel-titanium hand files. Restorative Dentistry and Endodontics 41:6-11.

Hartmann, R.C., Fensterseifer, M., Peters, O.A., de Figueiredo, J.A.P., Gomes, M.S., \& Rossi-Fedele, G. (2019) Methods for measurement of root canal curvature: a systematic and critical review. International Endodontic Journal 52(2):169-180.

Khandewal, D., Ballal, N.V., \& Saraswathi, M.V. (2015) Comparative evaluation of accuracy of 2 electronic Apex locators with conventional radiography: an ex vivo study. Journal of Endodontics 41(2):201-204.

Leeb, J. (1983) Canal orifice enlargement as related to biomechanical preparation. Journal of Endodontics 9(11):463-470. 
Leonardo, M.R., \& Leonardo, R.T. (2017) Tratamento de canais radiculares: avanços técnicos e biológicos de uma endodontia minimamente invasiva e reparadora. 2. ed. São Paulo: Artes Médicas.

Martins, J.N., Marques, D., Mata, A., \& Caramês, J. (2014) Clinical efficacy of electronic apex locators: systematic review. Journal of Endodontics 40(6):759777.

Nekoofar, M.H., Ghandi, M.M., Hayes, S.J., \& Dummer, P.M. (2006) The fundamental operating principles of electronic root canal length measurement devices. International Endodontic Journal 39(8):595-609.

Oliveira, T.N., Vivacqua-Gomes, N., Bernardes, R.A., Vivan, R.R., Duarte, M.A.H., \& Vasconcelos, B.C. (2017) Determination of the Accuracy of 5 Electronic Apex Locators in the Function of Different Employment Protocols. Journal of Endodontics 43(10):1663-1667.

Paqué, F., Zehnder, M., \& Marending, M. (2010) Apical fit of initial K-files in maxillary molars assessed by micro-computed tomography. International Endodontic Journal 43(4):328-335.

Paqué, F., Balmer, M., Attin, T., \& Peters, O.A. (2010) Preparation of oval-shaped root canals in mandibular molars using nickel-titanium rotary instruments: a micro-computed tomography study. Journal of Endodontics 36(4):703-707.

Pécora, J.D., Capelli, A., Guerisoli, D.M., Spanó, J.C., \& Estrela, C. (2005) Influence of cervical preflaring on apical file size determination. International Endodontic Journal 38(7):430-435.

Pereira, A. S., Shitsuka, D. M., Parreira, F. J. \& Shitsuka, R. (2018) Metodologia da Pesquisa Científica. 1. ed. - Santa Maria, RS: UFSM, NTE, 119 p.

Piasecki, L., Carneiro, E., da Silva Neto, U.X., Westphalen, V.P., Brandão, C.G., Gambarini, G., \& Azim, A.A. (2016) The Use of Micro-Computed Tomography to Determine the Accuracy of 2 Electronic Apex Locators and Anatomic Variations Affecting Their Precision. Journal of Endodontics 42(8):1263-1267.

Serna-Peña, G., Gomes-Azevedo, S., Flores-Treviño, J., Madla-Cruz, E., Rodríguez-Delgado, I., \& Martínez-González, G. (2020) In Vivo Evaluation of 3 Electronic Apex Locators: Root ZX Mini, Apex ID, and Propex Pixi. Journal of Endodontics 46(2):158-161.

Stöber, E.K., Duran-Sindreu, F., Mercadé, M., Vera, J., Bueno, R., \& Roig, M. (2011) An evaluation of root ZX and iPex apex locators: an in vivo study. Journal of Endodontics 37(5):608-610.

Thompson, S.A. (2000) An overview of nickel-titanium alloys used in dentistry. International Endodontic Journal 33(4):297-310.

Thomas, A.S., Hartwell, G.R., \& Moon, P.C. (2003) The accuracy of the Root ZX electronic apex locator using stainless-steel and nickel-titanium files. Journal of Endodontics 29(10):662-663.

Trope, M. (2010) Treatment of the immature tooth with a non-vital pulp and apical periodontitis. Dental Clinics of North America 54(2):313-324.

Üstün, Y., Aslan, T., Şekerci, A.E., \& Sağsen, B. (2016) Evaluation of the Reliability of Cone-beam Computed Tomography Scanning and Electronic Apex Locator Measurements in Working Length Determination of Teeth with Large Periapical Lesions. Journal of Endodontics 42(9):1334-1337.: 10.1016/j.joen.2016.06.010

Vasconcelos. B.C., Veríssimo Chaves, R.D., Vivacqua-Gomes, N., Candeiro, G.T., Bernardes, R.A., Vivan, R.R., \& Duarte, M.A. (2015) Ex Vivo Evaluation of the Accuracy of Electronic Foramen Locators in Root Canals with an Obstructed Apical Foramen. Journal of Endodontics 41(9):1551-1554.

Vasconcelos, B.C., Frota, L., \& Bernardes, R.A. (2020) Odontometria eletrônica em Endodontia: quando e como fazer o melhor uso dos localizadores eletrônicos foraminais. Dental Press Endodontics 10:12-19.

Vasconcelos, B.C., Matos, L.A., Pinheiro-Júnior, E.C., Menezes, A.S., \& Vivacqua-Gomes, N. (2012) Ex vivo accuracy of three electronic apex locators using different apical file sizes. Brazilian Dental Journal 23(3):199-204.

Vasconcelos, B.C., Bastos, L.M., Oliveira, A.S., Bernardes, R.A., Duarte, M.A., Vivacqua-Gomes, N., \& Vivan, R.R. (2016) Changes in Root Canal Length Determined during Mechanical Preparation Stages and Their Relationship with the Accuracy of Root ZX II. Journal of Endodontics 42(11):1683-1686.

Vasconcelos, B.C., Bueno, M.M., Luna-Cruz, S.M., Duarte, M.A., \& Fernandes, C.A. (2012) Accuracy of five electronic foramen locators with different operating systems: an ex vivo study. Journal of Applied Oral Sciences 21(2):132-137.

Vertucci, F., Seelig, A., \& Gillis, R. (1974) Root canal morphology of the human maxillary second premolar. Oral Surgery, Oral Medicine, Oral Pathology, Oral Radiology, and Endodontology 38:456-464.

Walia, H.M., Brantley, W.A., \& Gerstein, H. (1988) An initial investigation of the bending and torsional properties of Nitinol root canal files. Journal of Endodontics 14(7):346-351 